\title{
DAMPAK KEBIJAKAN SPIN-OFF TERHADAP KINERJA BANK SYARIAH
}

\author{
Amalia Nasuha*
}

\begin{abstract}
The Impact of Spin-Off Policy Towards Sharia Banks Performance. The purpose of this study is to discover differentiation financial performance of five sharia banks in Indonesia (BNI Syariah, BRI Syariah, BJB Syariah, Bank Syariah Bukopin, and Bank Victoria Syariah) one year before spin-off activity and one year after spin-off activity. The method used in this research is Wilcoxon Match Pairs Test with nine variables, which are asset, financing, third party funds, net incomes, dan five ratios: CAR, NPF, FDR, ROA, and ROE. The result of this study are, four variables indicate that there are differences in financial performance. Therefor, sharia business units should prepare themself before clause of spin-off in 2023 .
\end{abstract}

Keywords: spin-off, wilcoxon pair tests, financial performance

Abstrak: Dampak Kebijakan Spin-Off terhadap Kinerja Bank Syariah. Tujuan dari kajian ini adalah untuk menemukan perbedaan kinerja keuangan dari lima bank syariah di Indonesia yaitu BNI Syariah, BRI Syariah, BJB Syariah, Bank Syariah Bukopin, dan Bank Victoria Syariah satu tahun sebelum kegiatan pemisahan (spin-off) dan satu tahun setelah kegiatan pemisahan (spin-off). Metode yang digunakan ialah tes Wilcoxon dengan menggunakan sembilan variabel yaitu aset, pembiayaan, dana pihak ketiga, pendapatan bersih, dan lima rasion keuangan (CAR, NPF, FDR, ROA, dan ROE). Hasil yang didapat menunjukkan bahwa dari empat variabel menunjukkan adanya perbedaan kinerja keuangan. Dengan demikian, unit usaha syariah sebaiknya mempersiapkan diri sebelum jangka waktu pemisahan pada tahun 2023.

Kata Kunci: pemisahan, tes wilcoxon pair, kinerja keuangan

Naskah diterima: 6 Januari 2012, direvisi: 18 Mei 2012, disetujui: 24 Mei 2012.

* DPBs Bank Indonesia (BI). Jl. H.M. Thamrin No. 2, Jakarta Pusat, 10010. E-mail: amalia.nasuha@gmail.com. 


\section{Pendahuluan}

Pesatnya perkembangan perbankan syariah di Indonesia dipicu oleh lahirnya Undang-Undang No. 10 tahun 1998 yang memungkinkan perbankan menjalankan dual banking system. Bank-bank konvensional yang menguasai pasar mulai melirik dan membuka unit usaha syariah. Hingga Maret 2011, di Indonesia terdapat 11 Bank Umum Syariah (BUS), 23 Unit Usaha Syariah (UUS) di Bank Konvensional, dan 151 Bank Pembiayaan Rakyat Syariah.

Dari 11 BUS dan 23 UUS yang beroperasi, data statistik perbankan syariah per Oktober 2011 mencatat, untuk BUS total aset tahun 2005 sebesar Rp17,111 milyar dan meningkat 593\% menjadi Rp101,597 per Oktober 2011. Sedangkan UUS, total aset jauh meningkat sebesar 677\% dari Rp3,769 miliar pada 2005 menjadi Rp 25,553 per Oktober 2011. Melihat perkembangan BUS dengan UUS didapatkan bahwa pertumbuhan kinerja UUS lebih tinggi dibandingkan dengan BUS (Statistik Perbankan Syariah: Desember 2011)

Kinerja dan kontribusi perbankan syariah yang cukup pesat dalam sepuluh tahun terakhir ini membuktikan bahwa perbankan syariah memang sesuai dengan kebutuhan zaman. Upaya-upaya akselarasi perkembangan perbankan syariah tidak hanya dilakukan oleh Pemerintah dan Bank Indonesia sebagai regulator saja, tetapi juga perlu dukungan dari internal bank syariah, serta apresiasi positif penduduk Indonesia.

Dukungan dari semua stakeholder semakin terasa dengan disahkannya UU Perbankan Syariah No. 21 Tahun 2008 dan UU Surat Berharga Syariah Negara No. 19 Tahun 2008. Dengan adanya regulasi mandiri tersebut, eksistensi perbankan syariah di Indonesia menjadi semakin kuat. Tahun 2008 juga muncul trend baru pembentukan bank syariah melalui mekanisme akuisisi dan konversi bank konvensional menjadi bank syariah. Implementasinya dapat dilakukan melalui tiga pendekatan. Pertama, bank umum konvensional yang telah memiliki UUS mengakuisisi bank yang relatif kecil kemudian mengkonversinya menjadi syariah dan melepaskan serta menggabungkan UUS-nya dengan bank yang baru dikonversi tersebut. Kedua, bank umum konvensional yang belum memiliki UUS, mengakuisisi bank yang relatif kecil dan mengkonversinya menjadi syariah. Ketiga, bank umum konvensional melakukan pemisahan (spin-off) dan dijadikan Bank Umum Syariah tersendiri. ${ }^{1}$

Dari 11 Bank Umum Syariah (BUS), yang lahir murni melalui proses spinoff unit usaha syariah adalah Bank Jabar Banten Syariah dan BNI Syariah,

${ }^{1}$ Adiwarman A. Karim, Perbankan Syariah 2008: Evaluasi, Tren, dan Proyeksi, Research \& Management Division Head, (Jakarta: KARIM Business Consulting, 2008). 
sedangkan BUS lainnya banyak muncul melalui proses akuisisi, seperti Bank Syariah Mandiri berasal dari akuisisi Bank Susila Bakti, Bank Mega Syariah dari akuisisi Bank Umum Tugu, dan BCA Syariah melalui Bank Jasa Artha. Selain itu, proses spin-off melalui akuisisi, juga melalui konversi, seperti Bank Syariah Bukopin. BRI Syariah melalui Bank Jasa Artha, melalui Bank UIB, Bank Victoria melalui Bank Swaguna, dan Maybank Syariah melalui Maybank Indocorp.

Spin-off wajib dilakukan ketika bank konvensional memiliki UUS yang nilai asetnya minimal 50 persen dari total nilai aset bank induknya. Hal ini juga akan berlaku kepada semua UUS, 15 tahun setelah UU No. 21 Tahun 2008 disahkan. Ketentuan pada Pasal 68 ini menunjukkan bahwa unit usaha syariah yang masih memiliki induk konvensional adalah yang siap memisahkan diri dari induknya, sehingga menjadi badan usaha mandiri. Kesiapan ini diukur melalui kinerja perusahaan, seperti kinerja keuangan, manajemen, sumber daya manusia, jaringan, dan lainnya. Dampaknya akan memperlihatkan perkembangan bank syariah.

Permasalahan yang diajukan dalam studi ini adalah bagaimana perbedaan kinerja Bank Syariah (BNI Syariah, BRI Syariah, BJB Syariah, BSB, dan Bank Victoria Syariah) satu tahun sebelum dan satu tahun setelah melakukan spin-off.

Sehingga tujuan yang ingin dilakukan ialah untuk menganalisis kinerja Bank Syariah (BNI Syariah, BRI Syariah, BJB Syariah, BSB, dan Bank Victoria Syariah) satu tahun sebelum dan satu tahun setelah melakukan spin-off.

\section{Konsep Spin-Off}

Secara umum, spin-off menggambarkan suatu tambahan atau produk derivatif atau turunan atau hasil dari sesuatu tiruan usaha sebelumnya. Istilah spin-off sering dihubungkan dengan pembentukan perusahaan baru, di mana termasuk produk barunya adalah hal yang sama atau salinan dari organisasi induk, dan menimbulkan aktivitas ekonomi yang baru. Pemisahan ini bisa berbeda bentuk, tapi umumnya memerlukan perubahan yang penting pada kontrol, risiko, dan distribusi keuntungan. Unsur lainnya yaitu transfer teknologi dan hak kepemilikan dari induk kepada pemilik baru.

Dalam dunia korporasi internasional, istilah spin-off sebenarnya sudah tidak asing lagi karena telah banyak digunakan oleh perusahaan induk yang hendak melepas anak usahanya, atau divisi atau unit usaha. Namun, istilah spinoff di Indonesia masih terbilang baru, karena baru masuk dan diatur dalam Undang-Undang (UU). Definisi secara umum tentang spin-off perusahaan dijelaskan dalam UU Perseroan Terbatas Tahun 2007. Sedangkan spin-off bank disebutkan juga dalam UU No. 21 Tahun 2008 tentanng Perbankan Syariah. 
Kegiatan memunculkan usaha baru lebih banyak dikenal istilah tentang merger, akuisisi, dan konsolidasi.

Dalam Pasal 1 Angka 12 Pasal 135 UU PT No. 40 Tahun 2007 tentang Perseroan Terbatas, istilah spin-off disebut dengan pemisahan. Pemisahan didefinisikan sebagai berikut:

Perbuatan hukum yang dilakukan oleh Perseroan untuk memisahkan usaha yang mengakibatkan seluruh aktiva dan pasiva Perseroan beralih karena hukum kepada 2 (dua) perseroan atau lebih atau sebagian aktiva dan pasiva Perseroan beralih karena hukum kepada 1 (satu) Perseroan atau lebih.

Dari pengertian di atas dapat diketahui bahwa, pemisahan atau spin-off adalah suatu tindakan hukum yang bertujuan untuk memisahkan diri yang terjadi sebelumnya dalam suatu badan hukum kemudian ia 'memekarkan' atau 'membelah diri' dengan pengakuan hukum atas pemekaran atau pembelah diriannya tersebut. Kondisi pembelahdiriannya atau pemekaran badan hukum dalam bentuk perseroan terbatas tersebut diawali dengan kehendak dari para pihak yang tertuang dalam kesepakatan atau perjanjian yang dibuat oleh para pihak yang memiliki kewenangan dalam organ perseroan tersebut.

Kemudian, pada Pasal 1 angka 32 UU No. 21 Tahun 2008 tentang Perbankan Syariah, Pemisahan didefiinisikan sebagai berikut, "Pemisahan adalah pemisahan usaha dari satu bank menjadi dua badan usaha atau lebih sesuai dengan ketentuan yang berlaku".

Dari beberapa definisi di atas dapat disimpulkan mengenai spin-off. Pertama, akibat dari pemisahan akan muncul paling tidak satu perseroan baru. Kedua, pemisahan yang dilakukan adalah pemisahan usaha dan bukan pemisahan saham. Ketiga, terjadinya peralihan aktiva dan pasiva karena hukum.

Dalam dunia perbankan, khususnya perbankan syariah, alasan secara ekonomis mengapa terdapat keinginan Bank Umum Konvensional melakukan pemisahan Unit Usaha Syariah (UUS) dan dijadikan Bank Umum Syariah (BUS), oleh karena kegiatan usaha yang dapat dilakukan oleh BUS lebih luas dibandingkan dengan UUS dari Bank Konvensional. Kegiatan usaha yang hanya dapat dilakukan oleh BUS sebagaimana dimaksud adalah: (1) menjamin penerbitan surat berharga; (2) penitipan untuk kepentingan orang lain; (3) menjadi wali amanat; 
(4) penyertaan modal; (5) pendiri dan pengurus dana pensiun; (6) menerbitkan, menawarkan, dan memperdagangkan surat berharga jangka panjang syariah. ${ }^{2}$

Selain alasan-alasan ekonomis di atas, kegiatan spin-off sesungguhnya memiliki alasan ideologis, di mana pada awalnya istilah spin-off ini dilatarbelakangi oleh Undang-Undang Perbankan No. 10 Tahun 1998 yang menganut dual banking system. Sehingga supaya sistem konvensional dan syariah dapat berjalan sendiri-sendiri, mekanisme yang bisa digunakan adalah spin-off atau pemisahan. Dan pada akhirnya spin-off diatur dalam Undang-Undang No. 21 Tahun 2008, dengan didukung Peraturan Bank Indonesia No.11/10/2009, dan PBI lainnya.

\section{Konsep Kinerja}

Kinerja merupakan hasil pekerjaan yang mempunyai hubungan kuat dengan tujuan strategis organisasi, kepuasan konsumen, dan memberikan kontribusi pada ekonomi. Menurut Honggren dan Datar, pengukuran kinerja secara garis besar berdasarkan kriteria dan informasi yang dihasilkan dapat dibagi menjadi dua, yaitu pengukuran kinerja keuangan dan non keuangan.

Pengukuran kinerja keuangan biasanya menjabarkan tentang kinerja dari semua produk atau aktivitas jasa yang dihasilkan oleh perusahaan dalam satuan mata uang. Dasar yang digunakan adalah kinerja masa lalu sehingga pencapaian kinerja dan keunggulan bersaing yang diharapkan sangat sulit. Pengukuran kinerja non keuangan biasanya berhubungan dengan pengukuran fisik. Kinerja perusahaan pada bidang pengelolaan keuangan tingkat keberhasilannya dilihat pada kinerja keuangan. Efektivitas dan efisensi pada aktivitas-aktivitas perusahaan ditampakkan dalam laporan keuangan (neraca, laporan laba rugi, laporan perubahan modal, dan catatan atas laporan keuangan), dan tujuan perusahaan untuk mencapai tingkat laba yang optimal mencerminkan kinerja keuangan.

\section{Metode Analisis}

Dalam penelitian ini, jenis data yang digunakan adalah data sekunder yang berupa laporan keuangan bank syariah yang dipublikasikan oleh Bank Indonesia, bank-bank terkait, dan literatur-literatur yang berkenaan dengan spin-off dan kinerja perusahaan.

\footnotetext{
${ }^{2}$ Peri Umar Farouk, "Mekanisme Pembentukan Bank Syariah Alternatif: Akuisisi dan Konversi Bank Umum Konvensional serta Pemisahan (Spin-Off) Unit Usaha Syariah", dalam Jurnal Newsletter, No. 72/Maret/2009.
} 
Populasi dalam penelitian ini adalah hanya bank umum syariah yang lahir melalui spin-off. Adapun sampel yang digunakan adalah bank umum syariah yang lahir melalui spin-off minimal satu tahun, yaitu BNI Syariah, BRI Syariah, BJB Syariah, BSB, dan Bank Victoria Syariah. Dilihat dari metodenya, maka penentuan sampel seperti ini termasuk ke dalam teknik sampling purposive, yaitu teknik penentuan sampel dengan pertimbangan tertentu.

Studi ini menggunakan metode analisis kuantitatif, yaitu dalam pengolahan data berupa input dan output yang diambil dari neraca keuangan, laporan rugi laba, dan saldo laba yang dimiliki oleh masing-masing bank. Dalam analisis ini menggunakan Wilcoxon Match Pairs Test yang merupakan penyempurnaan dari uji tanda (sign test).

Kalau dalam uji tanda besarnya selisih nilai angka antara positif dan negatif tidak diperhitungkan, sedangkan dalam uji Wilcoxon ini diperhitungkan. Selain itu, penelitian ini menggunakan teknik analisis data Wilcoxon Match Pairs Test karena data yang digunakan berbentuk ordinal dan tidak berdistribusi normal. Teknik ini digunakan untuk menguji signifikansi hipotesis komparatif dua sampel yang berkorelasi dengan data yang berbentuk ordinal.

\section{Pembahasan}

Berikut ini adalah hasil dari gambaran laporan keuangan lima bank syariah hasil spin-off dilihat dari aset, pembiayaan, DPK, laba bersih, dan rasio-rasio yang meliputi: CAR, NPF, FDR, ROA, dan ROE.

\section{A s e t}

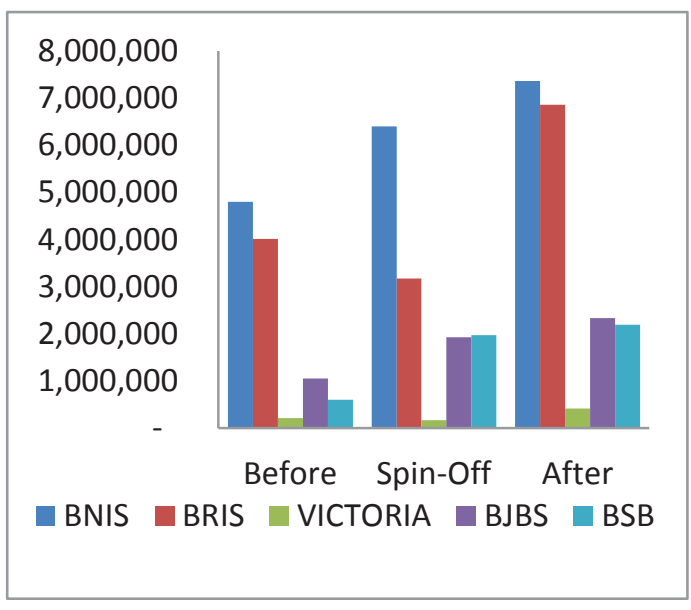

Sumber: Laporan keuangan publikasi masing-masing bank syariah, data diolah 
Dari grafik di atas dapat dilihat, pada sisi aset, tiga BUS konsisten meningkatkan aset nya selama tiga tahun, yaitu BNI Syariah, BJB Syariah, dan BSB. Aset BNI Syariah di tahun spin-off-nya meningkat 33\% dari tahun sebelumnya, 2009. Satu tahun berikutnya, 2011, aset BNI Syariah tumbuh 15\%. Untuk BJB Syariah, peningkatan aset dari tahun 2009 cukup jauh sebesar 83,6\% di tahun 2010, dan 20,8\% di tahun 2011. Bank Syariah Bukopin (BSB) mencatatkan per-tumbuhan aset yang fantastis. Tahun spin-off-nya yaitu 2009, aset BSB semula 606 milyar melonjak tajam 225\% menjadi 1,9 triliyun. Tahun 2010 meningkat sedikit sebesar $11 \%$ menjadi 2,19 triliyun.

\section{Dana Pihak Ketiga (DPK)}

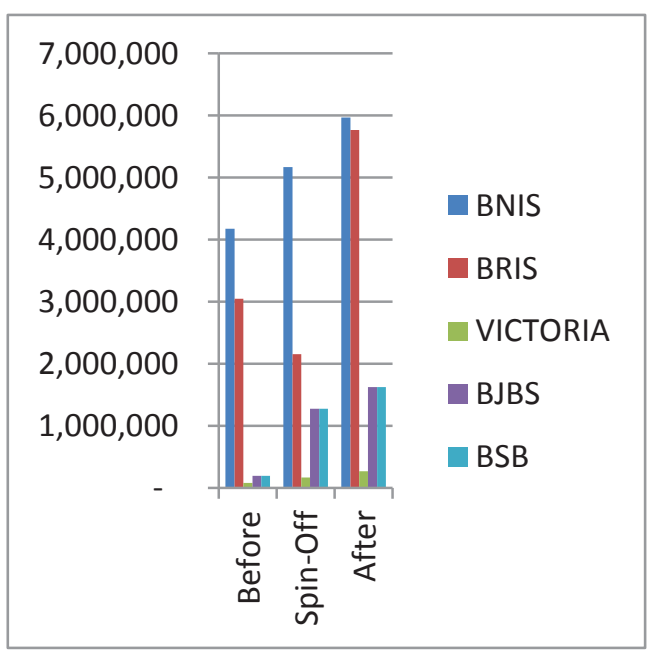

Sumber: Laporan keuangan publikasi masing-masing bank syariah, data diolah

Sementara itu, dua BUS lainnya yaitu BRI Syariah dan Victoria Syariah mengalami penurunan aset di tahun spin-off-nya sebesar 20\%. Namun 1 tahun pasca spin-off, kedua bank ini mencatatkan aset yang melonjak diatas 100\%. Aset BRI Syariah meningkat 115\% menjadi 6,8 triliyun, sedangkan Victoria Syariah, meskipun aset nya kecil, tapi peningkatan aset pasca spin-off terjadi sebesar 145\% menjadi 415 milyar. Dari sisi penghimpunan dana, dana pihak ketiga yang berhasil dihimpun keseluruhan bank dalam penelitian ini menunjukkan kinerja yang sangat baik. Tiga dari lima bank mencatatkan pertumbuhan di atas 100\%, bahkan DPK Bank Syariah Bukopin meningkat tajam 553\% dari Rp 195 milyar 
pada 2008 menjadi Rp 1,27 triliyun tahun 2009. Victoria Syariah meningkatkan aset nya hingga $116 \%$ di tahun 2010 dan 58,9\% di tahun 2011. Akan tetapi, kinerja penghimpunan dana BNI Syariah hanya meningkat sebesar $23,7 \%$ di tahun spinoff-nya, dan 15,5\% tahun berikutnya. BRI Syariah justru mencatatkan pertumbuhan negatif lagi di tahun 2010 sebesar 29,3\%. Namun satu tahun berikutnya, BRI Syariah membukukan tabungan, giro, dan deposito sebesar Rp 5,7 triliyun atau meningkat 167\% dari tahun sebelumnya sebesar Rp 2 triliyun.

\section{Laba Bersih}

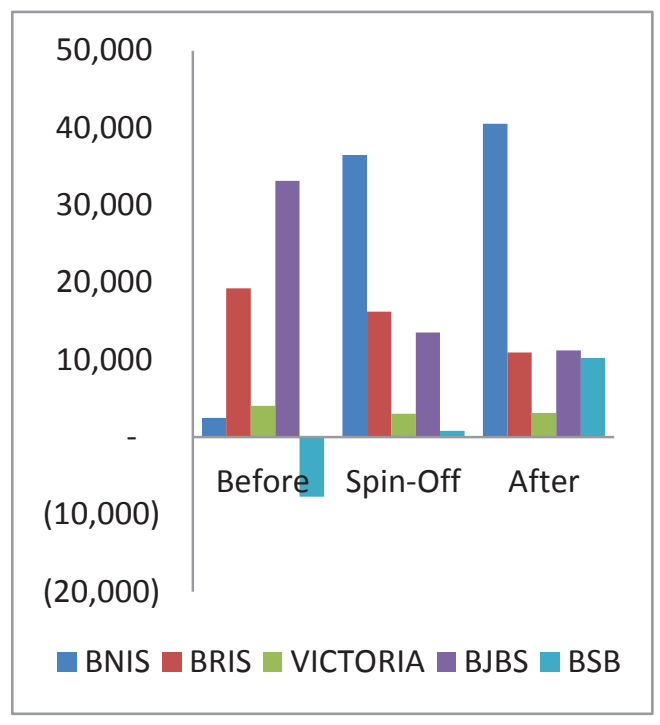

Sumber: Laporan keuangan publikasi masing-masing bank syariah, data diolah

Secara keseluruhan, bank-bank syariah dalam penelitian ini membukukan kerugian (laba negatif) hingga satu tahun setelah aktivitas spin-off-nya. Hal ini dapat dilihat dari grafik di atas, pada sebagian besar bank syariah grafik laba bersihnya menurun. BRI Syariah hingga 2011 mencatatkan laba yang semakin turun hingga 30 persen dari tahun 2010. Kemudian, meskipun masih negatif (rugi), laba bersih BJB Syariah menunjukkan perbaikan 40 persen. Victoria Syariah menyentuh level positif tahun 2011, pasca spin-off bank-nya. Laba bersih BSB meningkat Rp 45 milyar atau tumbuh 931\% dari minus Rp 4,83 milyar di akhir tahun 2008 menjadi Rp 831 milyar. Tahun 2010 atau satu tahun pasca spinoff, BSB terus meningkatkan laba bersihnya hingga mencapai Rp 10 milyar. 
Hanya BNI Syariah yang membukukan laba positif selama 3 tahun berturut-turut hingga mencapai Rp 40 milyar tahun 2011.

\section{Capital Adequacy Ratio (CAR)}

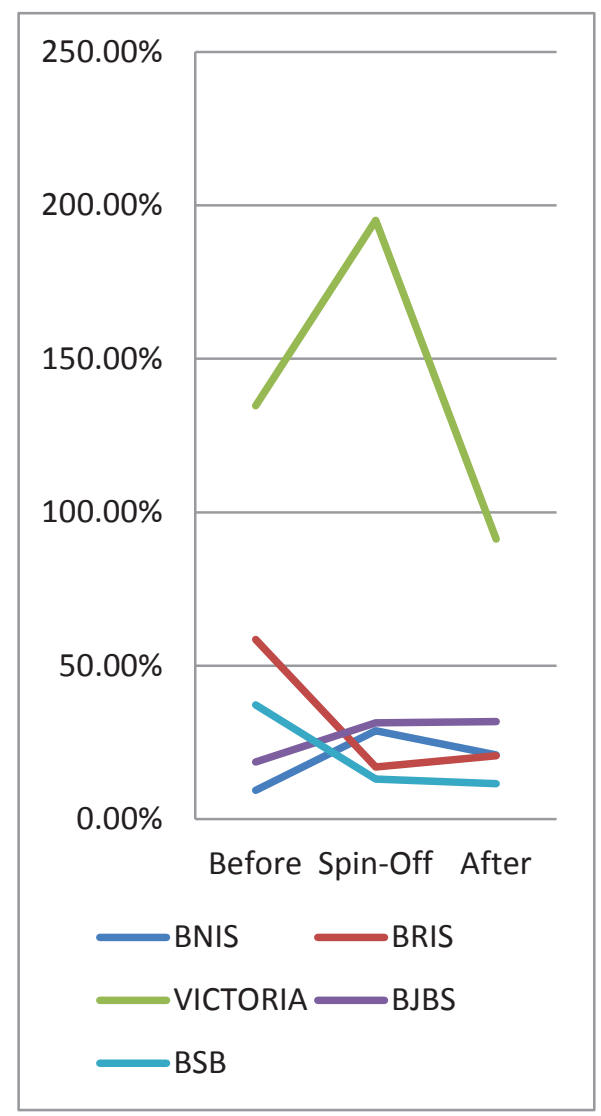

Sumber: Laporan keuangan publikasi masing-masing bank syariah, data diolah

Rasio kecukupan modal dari semua bank syariah dalam penelitian ini mengalami fluktuasi, namun sudah melampaui batas minimum CAR sebesar $8 \%$. CAR BRI Syariah menurun 70\% menjadi 17\% tahun 2010 dan naik 21\% tahun 2011, namun CAR Bank Syariah Bukopin yang turun 64,9\% ke angka 13\% tidak kembali membaik di tahun berikutnya, namun menurun lagi 11,9\% menjadi 11,51\%. Hal ini harus diperhatikan BSB agar meminimalisasi risiko kemungkinan kerugian dalam kegiatan perkreditan dan perdagangan surat berharga. Sedang- 
kan BNI Syariah dan Victoria Syariah justru mengalami penurunan rasio kecukupan modal nya di tahun pasca spin-off. CAR BNI Syariah turun 27\% menjadi 20,86\% dan Victoria Syariah turun 53\% menjadi 91,2\%.

\section{Non Performing Financing (NPF)}

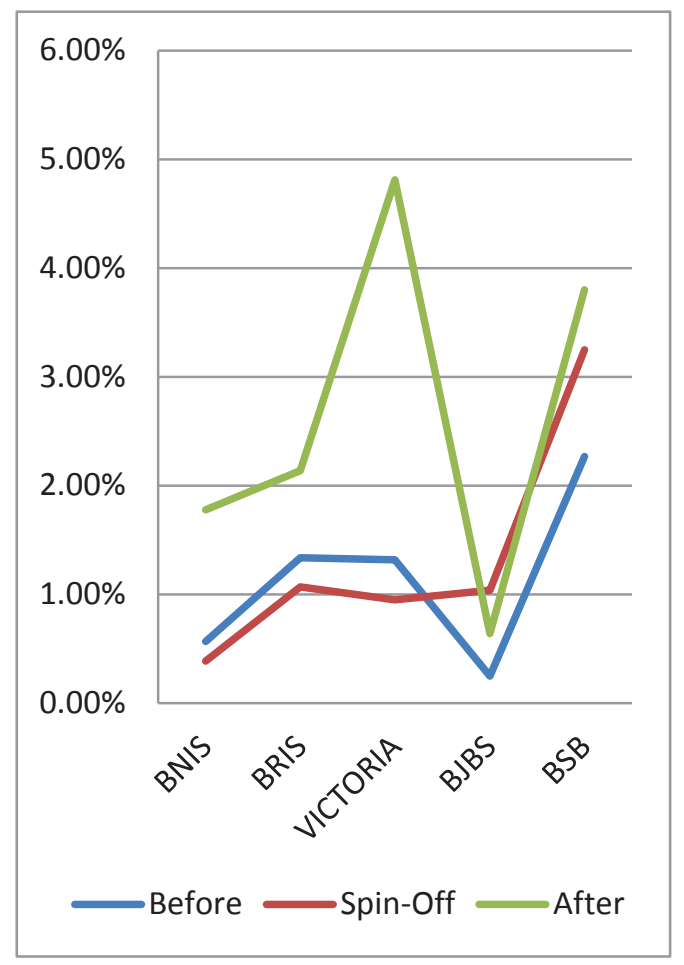

Sumber: Laporan Keuangan Publikasi masing-masing Bank Syariah, data diolah

Rasio gagal bayar dalam pembiayaan yang disalurkan, Non Performing Finance mengalami fluktuasi. NPF BNI Syariah, BRI Syariah, dan Victoria Syariah membaik dari tahun sebelum spin-off, yaitu masing-masing menjadi 0,39\%, $1,07 \%$, dan $0,95 \%$. Namun NPF ketiganya menurun 1 tahun setelahnya menjadi $1,78 \%, 2,14 \%$, dan 4,81\%. Sebaliknya, BJB Syariah baru memperbaiki NPF nya tahun 2011, pasca spin-off menjadi 0,64\%. Sementara itu, Bank Syariah Bukopin malah tidak menunjukkan NPF yang membaik. NPF BSB meningkat $43,2 \%$ di tahun 2009 menjadi 3,25\% dan $16,9 \%$ di tahun 2010 menjadi 3,80\%. 
Financing to Deposit Ratio (FDR)

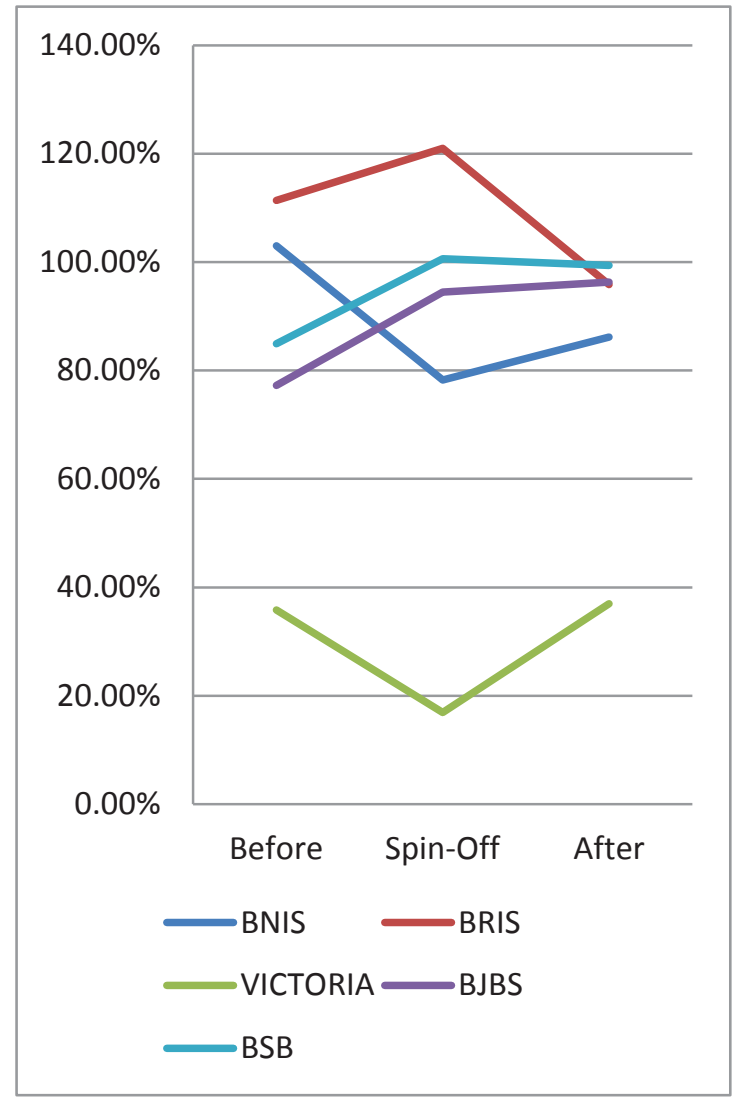

Sumber: Laporan keuangan publikasi masing-masing bank syariah, data diolah

Dalam hal kemampuan bank menyalurkan dana yang mereka himpun, FDR BNI Syariah dan Victoria Syariah mengalami penurunan sebesar $24 \%$ dan $52 \%$ ke angka $78 \%$ dan 16\%. Kemampuan Victoria Syariah dalam menyalurkan pembiayaan masih tergolong rendah karena berdasarkan FDR-nya yang hanya $37 \%$ pada tahun 2011. FDR tiga bank syariah lainnya meningkat pada tahun spinoff mereka. FDR BRI Syariah berada pada angka 120,98\% kemudian menurun 20\% menjadi 95,82\%. Kemudian FDR BJB Syariah tahun 2010 sebesar 94,5\% dan meningkat menjadi 96,34\%. Sedangkan Bank Syariah Bukopin mencatatkan kemampuan penyaluran pembiayaannya sebesar 100,62\% tahun 2009 dan 99,37\% tahun 2010 . 


\section{Return on Asset (ROA)}

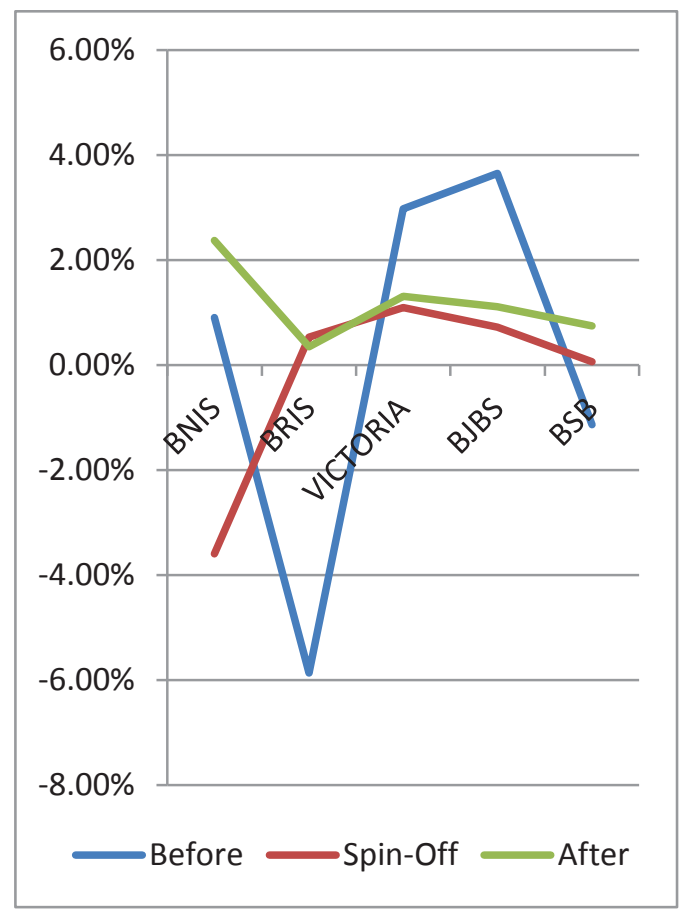

Sumber: Laporan keuangan publikasi masing-masing bank syariah, data diolah

ROA BJB Syariah dan Victoria Syariah meningkat masing-masing 20\% dan $54 \%$ ke angka $1,31 \%$ dan 1,11\%. Kenaikan ROA di tahun 2011 diakibatkan meningkatnya total aktiva, laba bersih, dan aset pada tahun yang sama. Bank Syariah Bukopin juga mencatatkan peningkatan nilai ROA nya menjadi $0,06 \%$ dan 0,74\% tahun 2010. Sedangkan untuk BNI Syariah kedua bank syariah ini mengalami peningkatan rasio perputaran asetnya menjadi positif. BNI Syariah mencatatkan ROA-nya sebesar 0,90\% tahun 2009, kemudian turun minus 3,60\% di tahun aktivitas spin-off nya, dan meningkat menjadi 2,37\% tahun berikutnya. Sedangkan ROA BRI Syariah meningkat di tahun spin-off-nya ke angka 0,53\% namun menurun di tahun berikutnya menjadi $0,35 \%$.

\section{Return on Equity (ROE)}

Nilai ROE BJB Syariah pada tahun 2011 sebesar 2,97\%, meningkat dari tahun 2010 pada angka $1.62 \%$ tercermin dari laba bersihnya yang meningkat di tahun 2009 dan menurun di tahun 2010 serta membaik di tahun 2011. Untuk ROE 
BNI Siariah terus tumbuh positif selama tiga tahun perjalanannya, dari 2009 sebesar 5\%, kemudian meningkat $12 \%$ tahun 2010 menjadi 5,6\% dan $11,6 \%$ tahun 2011. Sedangkan bank syariah lainnya tetap mengalami pertumbuhan positif pasca spin-off . ROE Victoria Syariah tumbuh 59\% dari 2,41\% pada tahun 2010 menjadi 3,84\% tahun 2011, juga ROE BSB yang meningkat tajam dari 0,87\% tahun 2009 menjadi 9,65\% tahun 2010. Namun ROE BRI Syariah turun dari 3,35\% menjadi $1,28 \%$ tahun 2010 .

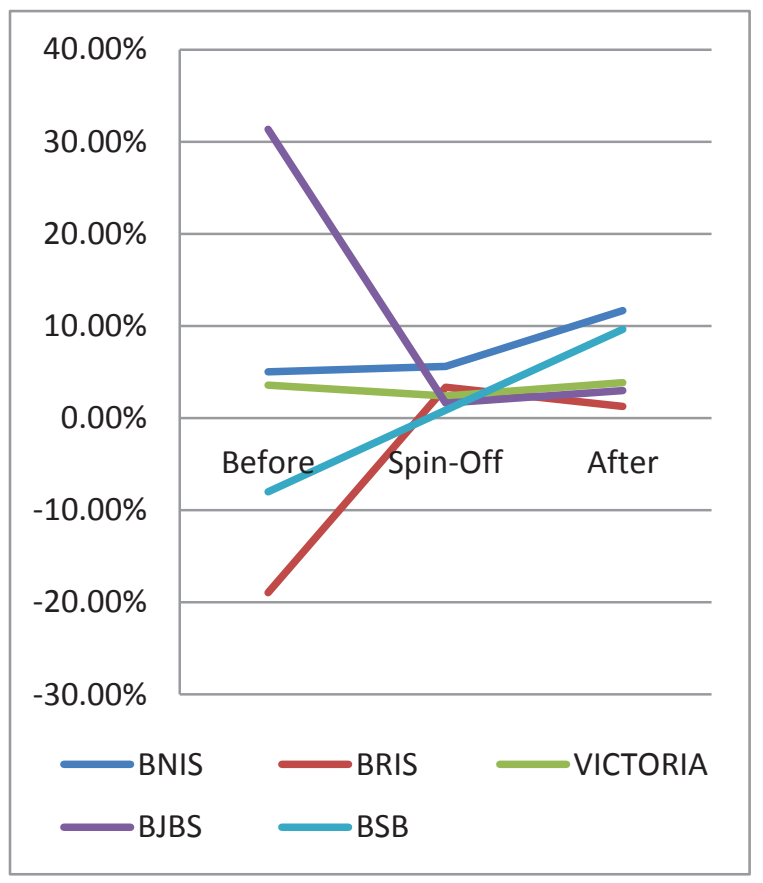

Sumber: Laporan keuangan publikasi masing-masing bank syariah, data diolah

\section{Pembiayaan}

Jumlah pembiayaan tahun 2009 sebesar Rp 3,265 triliun. Mengalami peningkatan yang cukup signifikan sebesar 84\% menjadi Rp 6 triliyun tahun 2010 . Dibandingkan posisi Juni 2010 saat dilaksanakannya spin-off, per September 2011, jumlah pembiayaan yang dilakukan BNI Syariah berupa qardh, murabahah, ijarah, dan pembiayaan lainnya mencapai Rp 6,925 triliun. Jumlah pembiayaan dari tahun 2008 sampai 2010 terus mengalami peningkatan. Tahun 2011, pembiayaan Victoria Syariah sebesar Rp 97 triliyun, jauh meningkat dari tahun sebelumnya sebesar Rp 27,903 milyar. Bank Jabar Banten Syariah meningkatkan 
pembiayaan nya sebesar $81 \%$ di tahun 2010 dari Rp 687 milyar menjadi Rp 1,2 triliyun dan meningkat lagi sebesar 31\% menjadi Rp 1,64 triliyun. Bank Syariah Bukopin meningkatkan pembiayaannya pasca spin-off sebesar $27 \%$ menjadi Rp 1,6 triliyun yang sebelumnya sebesar Rp 1,263 triliyun.

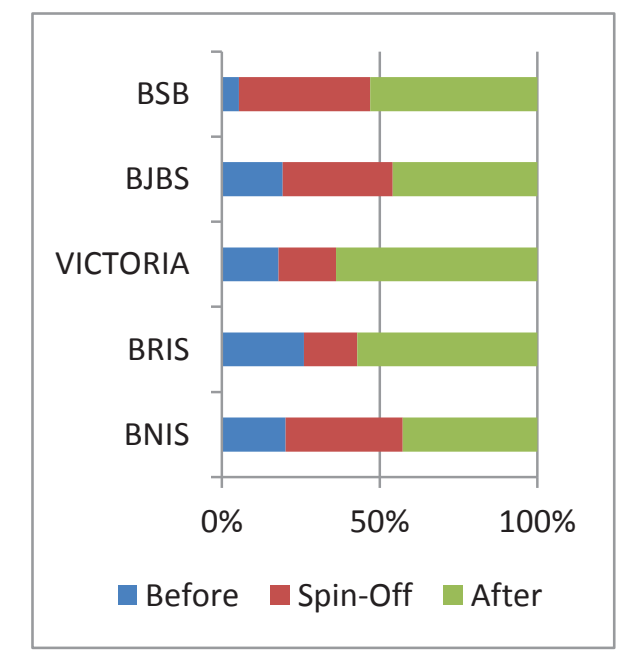

Sumber: Laporan keuangan publikasi masing-masing bank syariah, data diolah

\section{Analisis Data}

Pengujian hipotesis yang ada bertujuan untuk menjawab pertanyaan, apakah terdapat perbedaan antara kinerja bank syariah sebelum spin-off dan selama berlangsung spin-off. Analisis ini dilakukan untuk mengukur hipotesa yang menyatakan bahwa kinerja keuangan bank syariah secara parsial berbeda dengan signifikan antara sebelum dan sesudah spin-off, dengan menggunakan Wilcoxon Match Pairs Test. Pengujian dilakukan dengan uji Wilcoxon karena data yang digunakan adalah data yang tidak berdistribusi normal yang akan dikomparasikan.

Output hasil uji Wilcoxon Match Pairs Test, dapat disajikan dan dijelaskan pada tabel berikut: 
Tabel 1

Hasil Uji Wilcoxon Match Pairs Test

\begin{tabular}{cccccc}
\hline Hipotesis & Variabel & $\mathrm{Z}$ & $\mathrm{Sig}$ & $\mathrm{A}$ & Ketarangan \\
\hline $\mathrm{H}_{1}$ & Aset & -2.023 & 0.043 & 0.05 & Berbeda \\
\hline $\mathrm{H}_{2}$ & Pembiayaan & -2.023 & 0.043 & 0.05 & Berbeda \\
\hline $\mathrm{H}_{3}$ & DPK & -2.023 & 0.043 & 0.05 & Berbeda \\
\hline $\mathrm{H}_{4}$ & Laba Bersih & -0.135 & 0.893 & 0.05 & Tidak berbeda \\
\hline $\mathrm{H}_{5}$ & CAR & -1.214 & 0.225 & 0.05 & Tidak berbeda \\
\hline $\mathrm{H}_{6}$ & NPF & -2.023 & 0.043 & 0.05 & Berbeda \\
\hline $\mathrm{H}_{7}$ & FDR & -0.135 & 0.893 & 0.05 & Tidak berbeda \\
\hline $\mathrm{H}_{8}$ & ROA & -0.405 & 0.686 & 0.05 & Tidak berbeda \\
\hline $\mathrm{H}_{9}$ & ROE & -0.674 & 0.500 & 0.05 & Tidak berbeda \\
\hline
\end{tabular}

Sumber: Data diolah

Tabel 2

Hasil Perbandingan Kinerja

\begin{tabular}{ccccc}
\hline Hipotesis & Variabel & Negatif & Positif & Ties \\
\hline $\mathrm{H}_{1}$ & Aset & $0^{\mathrm{a}}$ & $5^{\mathrm{b}}$ & $0^{\mathrm{c}}$ \\
\hline $\mathrm{H}_{2}$ & Pembiayaan & $0^{\mathrm{a}}$ & $5^{\mathrm{b}}$ & $0^{\mathrm{c}}$ \\
\hline $\mathrm{H}_{3}$ & $\mathrm{DPK}$ & $0^{\mathrm{a}}$ & $5^{\mathrm{b}}$ & $0^{\mathrm{c}}$ \\
\hline $\mathrm{H}_{4}$ & Laba Bersih & $3^{\mathrm{a}}$ & $2^{\mathrm{b}}$ & $0^{\mathrm{c}}$ \\
\hline $\mathrm{H}_{5}$ & $\mathrm{CAR}$ & $3^{\mathrm{a}}$ & $2^{\mathrm{b}}$ & $0^{\mathrm{c}}$ \\
\hline $\mathrm{H}_{6}$ & $\mathrm{NPF}$ & $0^{\mathrm{a}}$ & $5^{\mathrm{b}}$ & $0^{\mathrm{c}}$ \\
\hline $\mathrm{H}_{7}$ & $\mathrm{FDR}$ & $2^{\mathrm{a}}$ & $3^{\mathrm{b}}$ & $0^{\mathrm{c}}$ \\
\hline $\mathrm{H}_{8}$ & $\mathrm{ROA}$ & $2^{\mathrm{a}}$ & $3^{\mathrm{b}}$ & $0^{\mathrm{c}}$ \\
\hline $\mathrm{H}_{9}$ & $\mathrm{ROE}$ & $1^{\mathrm{a}}$ & $4^{\mathrm{b}}$ & $0^{\mathrm{c}}$ \\
\hline
\end{tabular}

Sumber: Data Diolah

Hasil analisis data pada variabel Aset, Pembiayaan, DPK, dan NPF, dengan membandingkan kinerja bank syariah 1 tahun sebelum dengan 1 tahun sesudah spin-off, diperoleh nilai Z sebesar -2.023 dengan signifikansi sebesar 0.043 . Karena nilai signifikasi lebih kecil dari $0.05(0.043<0.05)$, berarti terdapat perbedaan pada beberapa variabel, yaitu Aset, Pembiayaan, DPK, dan NPF dengan masa periode perbandingan 1 tahun sebelum dengan 1 tahun sesudah spin-off.

Hasil analisis data pada variabel Laba bersih dan FDR, dengan membandingkan kinerja bank syariah 1 tahun sebelum dengan 1 tahun sesudah spin-off, diperoleh nilai Z masing-masing sebesar -0.135 dengan signifikansi sebesar 0.893 . Karena nilai signifikasi lebih besar dari $0.05(0.0893>0.05)$ maka berarti tidak 
terdapat perbedaan pada variabel laba bersih dan FDR dengan masa periode perbandingan 1 tahun sebelum dengan 1 tahun sesudah spin-off.

Hasil analisis data pada variabel CAR, dengan membandingkan kinerja bank syariah 1 tahun sebelum dengan 1 tahun sesudah spin-off, diperoleh nilai Z sebesar -1.214 dengan signifikansi sebesar 0.225. Karena nilai signifikasi lebih besar dari $0.05(0.225>0.05)$ maka berarti tidak terdapat perbedaan pada variabel CAR dengan masa periode perbandingan 1 tahun sebelum dengan 1 tahun sesudah spin-off.

Hasil analisis data pada variabel ROA, dengan membandingkan kinerja bank syariah 1 tahun sebelum dengan 1 tahun sesudah spin-off, diperoleh nilai Z sebesar -0.405 dengan signifikansi sebesar 0.686. Karena nilai signifikasi lebih besar dari $0.05(0.686>0.05)$ maka berarti tidak terdapat perbedaan pada variabel ROA dengan masa periode perbandingan 1 tahun sebelum dengan 1 tahun sesudah spin-off.

Hasil analisis data pada variabel ROE, dengan membandingkan kinerja 1 tahun sebelum dengan 1 tahun sesudah spin-off, diperoleh nilai Z sebesar -0.674 dengan signifikansi sebesar 0.500. Karena nilai signifikasi lebih besar dari 0.05 $(0.50>0.05)$ maka berarti tidak terdapat perbedaan pada variabel ROE dengan masa periode perbandingan 1 tahun sebelum dengan 1 tahun sesudah spin-off.

Dari output tersebut diperoleh: Pertama, negative ranks. Tidak ada selisih antara variabel sebelum dan sesudah yang negatif atau dengan kata lain tidak terdapat observasi pada variabel sesudah yang kurang dari observasi pada variabel sebelum. Kedua, positive ranks atau selisih variabel sebelum dan sesudah yang positif sebanyak 5 observasi atau dengan kata lain terdapat 5 observasi pada variabel sesudah yang lebih dari observasi pada variabel sebelum dengan rata-rata rangkingnya $=3$ dan jumlah rangking positif $=15$. Ties atau tidak ada perbedaan antara variabel sebelum dan sesudah sebanyak 0 observasi.

Potensi yang dimiliki perbankan syariah secara keseluruhan menunjukkan bahwa perlu adanya rencana-rencana ke depan yang strategis dan memenuhi kebutuhan pasar. Rencana tersebut dirumuskan melihat prospek, tantangan, dan kesempatan yang ada, sehingga akselarasi perbankan syariah dapat lebih maksimal dijalankan. Undang-Undang No.10 Tahun 1998 merupakan dasar utama tercetusnya usulan spin-off bagi bank syariah. Hal ini disebabkan dalam UU No.10 Tahun 1998 tersebut memperbolehkan di Indonesia menganut dual system banking, yaitu bank dengan sistem kovensional dan syariah. Menanggapi hal tersebut, pemerintah, dalam hal ini Bank Indonesia, membuat rencana jangka panjang, agar tidak lagi terjadi dualisme sistem perbankan dalam satu 
tubuh, perlu ada kemandirian dari masing-masing sistem dan siap bersaing. Spin-off kemudian diatur dalam UU No. 21 Tahun 2008. Spin-off juga dimaksudkan dalam rangka mempercepat laju pertumbuhan bank syariah, yaitu mendorong Unit Usaha Syariah untuk memisahkan dirinya (spin off) dari bank induknya atau konversi dari bank konvensional menjadi bank syariah.

\section{Penutup}

Dari hasil pengujian didapatkan, dari sembilan variabel yaitu aset, pembiayaan, DPK, laba bersih, CAR, NPF, FDR, ROA, dan ROE yang diuji dengan metode Wilcoxon Signed Ranks Test menunjukkan bahwa perbedaan kinerja antara sebelum dan sesudah spin-off terjadi pada tiga variabel, yaitu: aset, pembiayaan, dan dana pihak ketiga (DPK). Hal ini dapat dilihat dari nilai signifikansi yang kurang dari $\alpha$. Artinya, terdapat pengaruh sebelum aktivitas spinoff dan sesudah. Sedangkan pada variabel lainnya, CAR, FDR, ROA, dan ROE tidak menunjukkan perbedaan kinerja antara satu tahun sebelum dan satu tahun sesudah spin-off, dengan nilai signifikansi lebih besar dari $\alpha$. Hal ini mungkin disebabkan karena spin-off masih baru dipraktikkan di industri perbankan syariah, sehingga jangka waktu pengujian masih pendek.

Dalam menyiapkan diri berpisah dari bank kovensional menjadi BUS yang mandiri, rencana bisnis perlu disiapkan dengan matang sejak masih UUS. UUS perlu mengalkulasikan secara serius investasi awal yang disiapkan untuk spinoff, seperti: (a) Bank-bank syariah memiliki rencana bisnis dengan action plan, di mana rencana spin-off tertuang di sana. Selain itu juga fokus pengembangan bisnis bank syariah jangka pendek, jangka menengah, dan jangka panjang; (b) Peningkatan kualitas SDM dan IT dilakukan dengan ragam cara masing-masing bank. Melakukan training intensif, penguatan ruhiyah, serta menjalin kerja sama dengan lembaga, perguruan tinggi yang sudah memiliki calon-calon SDM untuk industri perbankan syariah; (c) Karena bank-bank syariah yang lahir melalui proses spin-off masih berumur satu hingga dua tahun, maka bank syariah akan memperbesar asetnya. Menjaring nasabah dan melakukan kerja sama dengan pelbagai pihak; (d) Mengembangkan produk-produk perbankan syariah yang applicable dengan jaringan pelayanan yang tersebar di masyarakat. []

\section{Daftar Pustaka}

\section{Buku:}

Anshori, Abdul Ghofur, Pembentukan Bank Syariah Melalui Akuisisi dan Konversi, Yogyakarta: UII Press, 2010. 
Karim, Adiwarman A., Perbankan Syariah 2008: Evaluasi, Tren, dan Proyeksi. Research \& Management Division Head, Jakarta: KARIM Business Consulting, 2008.

Muhammad, Bank Syariah, Problem dan Prospek Perkembangan di Indonesia, Yogyakarta: Graha Ilmu, 2005.

Rochaety, Ety, dkk. Metodologi Penelitian Bisnis dengan Aplikasi SPSS. Jakarta: Mitra Wacana Media, 2007.

Tubke, Alexander. Success Factors of Corporate Spin-Offs. USA: Springer Science, Inc.

Umar, Husein, Metode Riset Bisnis. Jakarta: PT Gramedia Pustaka Utama, 2003. Wibowo, Manajemen Kinerja. Jakarta: PT Raja Grafindo, 2007.

\section{Artikel/Makalah:}

Afrizal, Afick, "Sebuah Analisis tentang spin-off", Artikel diakses pada tanggal 25 September 2011 dari http://afick-afrizal.blogspot.com/2009/01/sebuahanalisis-tentang-spin-off.html.

Farouk, Peri Umar, "Mekanisme Pembentukan Bank Syariah Alternatif: Akuisisi dan Konversi Bank Umum Konvensional serta Pemisahan (Spin-Off) Unit Usaha Syariah", Jurnal Newsletter No.72/Maret/2009.

Hetami, Adietya Arie, "Pengaruh Motivasi, Kemampuan, dan Disiplin terhadap Kinerja Karyawan”, POLIBIS Jurnal Ekonomi dan Bisnis, Volume 7, Nomor 1, Maret 2009.

NN, "Spin-off, Konstruksi Hukum dalam Upaya Penguatan Struktur Perbankan Nasional", Buletin Hukum Perbankan dan Kebanksentralan, Vol. 7, Nomor 1, Januari 2009.

Statistik Perbankan Syariah Maret 2011, http://www.bi.go.id/web/id/Statistik/ Statistik+Perbankan/Statistik+Perbankan+Syariah/spss_0211.htm, tanggal akses 6 Mei 2011.

\section{Perundang-undangan:}

Undang-Undang Nomor 21 Tahun 2008 tentang Perbankan Syariah.

Undang-Undang Nomor 40 Tahun 2007 tentang Perseroan Terbatas.

\section{Website:}

www.bnisyariah.co.id www.bjbsyariah.co.id www.brisyariah.co.id, dll. 